\title{
DEVELOPMENT OF MUSIC-BASED LEARNING MODELS TO INTRODUCE LETTERS AND NUMBERS OF EARLY CHILDHOOD
}

\author{
Risdianto Hermawan ${ }^{1}$ \\ ${ }^{1}$ Universitas Ma'arif Nahdlatul Ulama Kebumen
}

\begin{abstract}
Basically, early childhood has extraordinary abilities, especially in the process of development. Therefore, it is necessary to optimize child development appropriately, and avoid burdening or forcing children. One of the strategies in developing early childhood education is through a music-based learning model. This study aims to describe and analyze how the development of a music-based learning model to introduce letters and numbers in early childhood. This papper is methodologically close to development research or what is commonly called Research and Development. The results of the development of a music-based learning model to introduce letters and numbers in early childhood are a form that is implemented to develop students' knowledge and abilities in recognizing letters and numbers. This research also produces a product in the form of music that can be applied to provide material for introducing letters and numbers to children. Students tend to be more able to understand or recognize letters and numbers using music so that children's abilities and understanding develop more optimal.
\end{abstract}

Keyword: Music-Based Learning, Reading and Counting

\begin{abstract}
Abstrak: Pada dasarnya anak usia dini memiliki kemampuan yang luar biasa terutama dalam proses perkembangannya. Oleh karena itu, perlu mengoptimalkan perkembangan anak secara tepat, dan menghindari membebani atau memaksa anak. Salah satu strategi dalam mengembangkan pendidikan anak usia dini adalah melalui model pembelajaran berbasis musik. Penelitian ini bertujuan untuk mendeskripsikan dan menganalisis bagaimana pengembangan model pembelajaran berbasis musik mengenalkan huruf dan angka pada anak usia dini. Makalah ini secara metodologis dekat dengan penelitian pengembangan atau yang biasa disebut Research and Development. Hasil pengembangan model pembelajaran pengenalan huruf dan angka berbasis musik pada anak usia dini merupakan bentuk yang dilaksanakan untuk mengembangkan pengetahuan dan kemampuan siswa dalam mengenal huruf dan angka. Penelitian ini juga menghasilkan produk berupa musik yang dapat diterapkan untuk memberikan materi pengenalan huruf dan angka kepada anak. Siswa cenderung lebih mampu memahami atau mengenal huruf dan angka dengan menggunakan musik sehingga kemampuan dan pemahaman anak berkembang lebih optimal.
\end{abstract}

Kata Kunci: Pembelajaran, Membaca, dan Berhitung Berbasis Musik

\footnotetext{
' Universitas Ma'arif Nahdlatul Ulama Kebumen, Email: ianhermawanr国gmail.cum
} 


\section{INTRODUCTION}

Early childhood education (PAUD) is a period where children have not yet entered formal education age. Early childhood is the right time to develop a variety of potential. Potential development that is done well will have an impact to a good future life. Early childhood education should use a fun learning model. Fun learning is a stimulus designed to condition children to develop their potential for intelligence. Fun learning is also meaningful learning that will continue to make an impression in the child's life so that children will more easily get information from the teacher. One learning model that is fun and can introduce letters and numbers in early childhood is a music-based learning model. With a music-based learning model, children are increasingly motivated to learn and will get optimal results. Especially in recognizing letters and numbers, so that later children will find it easier to learn to read and count.

Most of the previous theories explained that early childhood is prohibited from learning to read, write and count. However, all of that must be seen from the level of development of the child itself. The learning model must also be adapted to the level of early childhood development. Thus, there is no harm if children being introduced to or learning read, write and count as long as it is adjusted to the child's level of development.

\section{METHOD}

The research with the title "Development of Music-Based Learning Model to Introduce Letters and Numbers in Early Childhood in Al Azkia IAIN Purwokerto PlayGroup" is methodologically close to development research or commonly called Researh and Development (R\&D) (Sugiyono, 2014). This research is oriented towards the development of products used for problem solving the introduction of letters and numbers in early childhood in the Al Akia PlayGroup IAIN Purwokerto. The product developed is a music-based learning model.

This study uses three approaches, namely: (1) the response of prospective users of the learning model which is held at the beginning through interview discussions with informants about the trial plan and at the end to see the results of trials and stabilization; (2) qualitative approaches are used for ciba I (limited) and II (main) trials to develop prototypes into learning models using music or song media; and (3) qualitative approaches are used for experiments to test the effectiveness and validation of learning models using music media or songs to introduce letters and numbers compared to the learning models used by teachers so far. After that, the new learning media acceptance test was conducted.

\section{RESULTS AND DISCUSSION Early Childhood Learning Model}

The term learning model is taken from two syllables, namely model and learning. Where each of these words has a different meaning. According to Good and Traves (Fadlillah, 2016, pp. 181) a model is an abstraction of the real world or a representation of complex events in the form of narrative, mathematical, graphic, and other symbols. In addition, models are often interpreted as an object or concept that is used to present something real and converted to a more comprehensive form (Fadlillah, 2016).

Learning requires a conscious process that tends to be permanent and change behaviour. In this process, information is recalled which is then stored in memory and cognitive organization. Furthermore, these skills are practically manifested in the activeness of students in responding and reacting to events that occur to students or their environment (Thobroni, 2016).

Learning is essentially a process of interaction between children and children, 
children with learning resources, and children and educators. Learning activities like this will be meaningful for children if carried out in a comfortable environment and provide a sense of security for children. The learning process is individual and contextual. This means that the learning process occurs within the individual according to their development and their environment (Majid, 2014).

Piaget formulated that the learning process can take place if there is an active data processing process on the part of the learner. Active data processing is a continuation of information seeking activities followed by discovery activities (Majid, 2014).

The music-based learning model is a learning process that is specifically presented by the teachers by using music as the main medium. In this case, music is the main ingredient in implementing the approach to learning methods, strategies, and techniques. The music-based learning model in this study is used to introduce letters and numbers in early childhood.

This learning model is synonymous with singing in early childhood. Singing is one of the learning methods that use chanted verses. Usually, the verses are adjusted to the learning materials to be delivered. According to the expert's opinion, singing or using music will make the learning atmosphere cheerful and excited, so that early childhood development can be stimulated more optimal. In principle, the task of early childhood education institutions is to develop all aspects of students, including physical motor, social, emotional, intellectual, language and art, as well as morals and religion (Fadlillah, 2016).

From the description above, it illustrates that singing activities cannot be separated from early childhood education. Children really like to sing, clap their hands and also dance. By using music or singing in each lesson, children will be more optimally informed, especially in language and interacting with their environment.

Children have several bits of intelligence, all of which must be developed. One of them is musical intelligence. Musical intelligence is the ability to store notes, remember rhythms, and be emotionally affected by music. Therefore, music can also be called the language of emotions that can affect a person's heart. Even music can open the deepest feelings of the heart and this cannot be done by any other art (Helmiati, 2012).

There are some learning materials that are enough to make children feel difficult in thinking and memorizing them, this kind of thing can be helped by using music to make the material easier to memorize and understand. When educators will provide material that sometimes makes children bored, actually educators can create conditions that make children comfortable and relaxed, such as by listening to the music (Helmiati, 2012). In every learning process, early childhood does not only use their sight but also uses their hearing. Even what they saw and heard, they will remember (Acredolo and Goodwyn, 2010).

Singing is a learning method that uses chanted verses (Acredolo and Goodwyn, 2010). In using this method, usually, a teacher makes verses related to the material to be conveyed to the children. The hope is that by making the lyrics according to the material and in this way it will make it easier for children to absorb and understand the material presented.

When this singing method is applied when delivering learning materials to early childhood, it will make the learning atmosphere excited, cheerful, and happy. Music-based learning in early childhood usually does not always involve teaching children to sing, but also developing other aspects of development that the child has. So that the development 
of children will run or take place optimally.

\section{Playing, Singing, and Activities}

The approach to early childhood education that is most appropriate to their psychological, pedagogical, and stage of moral development is an approach that puts forward the aspects of playing, singing (having fun) and working in the sense of doing activities (Riyanto, 2012).

Playing, singing, and doing activities are the three most appropriate features of early childhood education. Starting from training, learning, and all existing activities in early childhood education, it should be covered with active playing, singing, and activities or work. With these three things, the child's brain will be honed and the child's development will also be optimally stimulated. This is because when learning, children do it cheerfully, freely, and carefree. So that learning material will be easily absorbed by children.

\section{Reading For Early Childhood}

Early reading is reading that is taught programmatically to preschoolers. This program fosters attention to complete, meaningful speech in the personal context of the children and the materials provided through interesting games and activities as learning mediums (Susanto, 2011).

So far, developmental psychology theory driven by Jean Piaget has become the main reference for the kindergarten curriculum. As a result, lessons in reading, writing and arithmetic or labia de-known as calistung are indirectly prohibited from being introduced to children under 7 years of age. This is because Piaget thinks that children under 7 years of age have not yet reached a concrete phase. The phase-in question is the phase where the child can think in a structured manner. So that Calistung is defined as an activity that requires structured thinking (Aulia, 2016).
In essence, reading can be introduced at an early age, it's just that it needs to pay attention to the development and abilities of children. Because every child has different abilities and levels of development, some are still difficult to translate language symbols (letters) into sounds, there are also children who are fast in their development and abilities. Therefore, it is necessary to deliver appropriate levels of ability and early childhood development.

\section{Analysis of Students' Needs on Music- Based Learning Models to Introduce Letters and Numbers in Early Childhood in Al-Azkia Playgroup, Purwokerto}

Based on the data obtained, it can be described that from 23 children interviewed, there were 23 children who liked to sing or liked the music (singing). Meanwhile, there is no child who thinks does not like singing. Most of the children said that they liked the music (singing). There are only a few who say they don't like music or singing.

From the questions posed, it can be concluded that early childhood, on average or mostly like music (singing). On the other hand, the Al-Azkia Play Group also uses singing every day to start every activity. For example, when the child first enters class, the teacher directs the child to make a circle. When the child is in the position of making a circle, the teacher invites the child to sing in a circle to start children's activities.

The researchers asked 23 students about how often the teacher taught or sang in class. All children answered that the teacher always sings in starting learning activities and developing cognitive intelligence of students in the Al-Azkia Play Group IAIN Purwokerto.

When the child is asked about the pitch of the song using observations, the teacher gives an example by singing high, medium, and low pitched songs. Of the 23 students, 10 students answered that they 
liked songs with high notes, 12 children answered that they preferred songs with varied tones, some were high and some were low, while 1 student answered that they preferred songs using low tones.

In this question, the teacher sings 3 songs with different tones, namely my balloon song which is song with a variety of different tones (high notes, varied or mixed notes, and low notes). From here the child listens and observes and answers the choice of a pitch he likes.

To find out that students like songs with fast, medium, or slow tempo, researchers and teachers give questions to students by singing my balloon song which is song with different tempos, namely fast, medium and slow tempo. Of the 23 students, 5 chose or preferred fast tempo songs, 10 students chose medium tempo songs, while 8 children preferred slow tempo songs. From this, it can be concluded that students in the Al-Azkia Play Group prefer or like songs with a medium tempo. Of the 23 students, 10 students chose medium tempo.

After conducting the interview which is then written in the table above, of the 23 students, 23 of them preferred songs with a happy or pleasant atmosphere. Meanwhile, there were no students who liked songs with a sad atmosphere. This means that all children like songs with a happy or fun atmosphere.

To find out the understanding of students in the Al-Azkia IAIN Purwokerto Play Group on the recognition of letters and numbers or in this case, more specifically on the material of letters and numbers, the researcher asked some questions to students about understanding and recognizing letters and numbers in early childhood in the group. Playing AlAzkia IAIN Purwokerto.

After conducting interviews about the material of letters and numbers through a music-based learning model, the results of the interview or data were obtained. It can be seen that from 23 students who studied in the Al-Azkia Play Group IAIN Purwokerto, and this was confirmed by interviews conducted with teachers or mothers there. From the results of this interview, it was concluded that 10 children had mastered or memorized the letters in the right order, on the other hand, there were 13 children who had not memorized the order of the letters of the alphabet correctly.

In addition to understanding letters, researchers also asked about understanding numbers in students in the Al-Azkia Play Group IAIN Purwokerto. To test the understanding of numbers in students there, the researchers also used the same method as above.

It is known that of the 23 students in the Al-Azkia IAIN Purwokerto Play Group, 20 students already know and memorize the sequence of numbers correctly. Meanwhile, there were 3 students who were still inaccurate in stating the sequence of numbers. At the time of the interview, only about 13 students were included in the category of memorizing the sequence of numbers correctly and mentioning the sequence using a song. While the other 10 students memorize the sequence of numbers without using songs.

From the answers of these students, it can be concluded that they are better and more precise in memorizing children who use songs or music when compared to students who memorize without using songs. Therefore, in addition to making it easier to memorize, music or songs also make the learning atmosphere of students in the Al-Azkia Play Group more fun and enjoyable.

From the last question asked, 21 students in the Al-Azkia Play Group prefer songs with short lyrics. Meanwhile, the remaining 2 prefer songs with long lyrics. Short lyrics are easier to memorize and understand when compared to long lyrics.

From all the questions asked of students in the Al-Azkia IAIN Purwokerto 
Play Group, the music-based learning model is considered more effective for children to understand learning material when compared to learning or material presentation that does not use music. In addition, music-based learning is considered effective and is also strengthened when students in the AlAzkia Play Group are asked to memorize the letters of the alphabet and numbers in the right order.

Children who can pronounce the sequence of letters and numbers correctly and accurately, most of them say using songs. Meanwhile, children who do not correctly mention letters and numbers do not use songs to memorize them. Children often forget and stutter or have to be guided so that they can say letters and numbers in the right order.

\section{Analysis of Teacher Needs on Music- Based Learning Models to Introduce Letters and Numbers in Early Childhood in the Al Azkia IAIN Purwokerto Play Group.}

From 4 teachers, the researcher asked questions about how often the teacher taught through music in class. 3 out of 4 teachers answered that they always sing when starting learning activities so that the atmosphere in the classroom becomes fun.

When the teacher is asked about the pitch of the song that the teacher likes to sing or prefers 1 teacher answered that they liked songs with high tones, 2 teachers answered that they preferred songs with varied tones, some were high and some were low, while 1 other teacher answered that they preferred songs using low tones.

In addition to the favourite factor, more teachers choose various tones due to the sound factor that each teacher has. Not all teachers can sing high notes. So that 2 out of 4 teachers prefer a varied tone. The mix of high and low notes, apart from making it easier for the teacher to sing, can also make the music and learning atmosphere more excited and easy for students to understand.

To find out that the teacher likes songs with fast, medium, or slow tempo, the researcher asks the teacher a question. Of the 4 teachers interviewed, 1 teacher chose or preferred a fast tempo song, 3 teachers chose a medium tempo song, while no one chose a slow tempo, the teacher thought that a slow tempo song made the atmosphere less enthusiastic. From this, it can be concluded that the teachers in the Al-Azkia Play Group prefer or like songs with a medium tempo. Of the 4 teachers, 3 students chose medium tempo, 1 other teacher chose fast tempo.

After the interview was conducted which is then written in the table above, of the 4 teachers interviewed, all the teachers preferred songs with a happy or pleasant atmosphere. Meanwhile, there were no teachers who liked songs with a sad atmosphere. This means that all teachers like songs with a happy or pleasant atmosphere.

The material in the song lyrics that the teacher wants, from 4 teachers 1 teacher chooses material that is easy to memorize, 2 teachers choose the material that is easy to memorize and sung often , while other teacher chooses varied material. Likewise in teaching material to their students, each teacher chooses their own way according to their wishes. Of the 4 teachers, 2 teachers used to teach letters using posters in the classroom, 1 teacher guided the children to thicken letters. And 1 other prefers to use songs.

In teaching number recognition, 1 teacher usually uses posters to introduce them, 1 other teacher thickens letters, while 2 other teachers prefer to use songs. In addition to teaching methods, when being interviewed about the lyrics desired by the teacher, all the teachers preferred to use songs that had short lyrics and repeated, in this case none of the teachers chose to use long lyrics. 
From the two data above, it can be concluded that a music-based learning model for introducing letters and numbers in early childhood in the Al-Azkia Play Group can be done. This is because musicbased learning to introduce letters and numbers is tailored to the needs and desires of students and teachers in the AlAzkia IAIN Purwokerto Play Group.

\section{Results of the Design of a Music-Based Learning Model to Introduce Letters and Numbers in Early Childhood}

The design results from the development of this music-based learning model are designed using an encore application and are also made in the form of a music recording file which is described as follows:

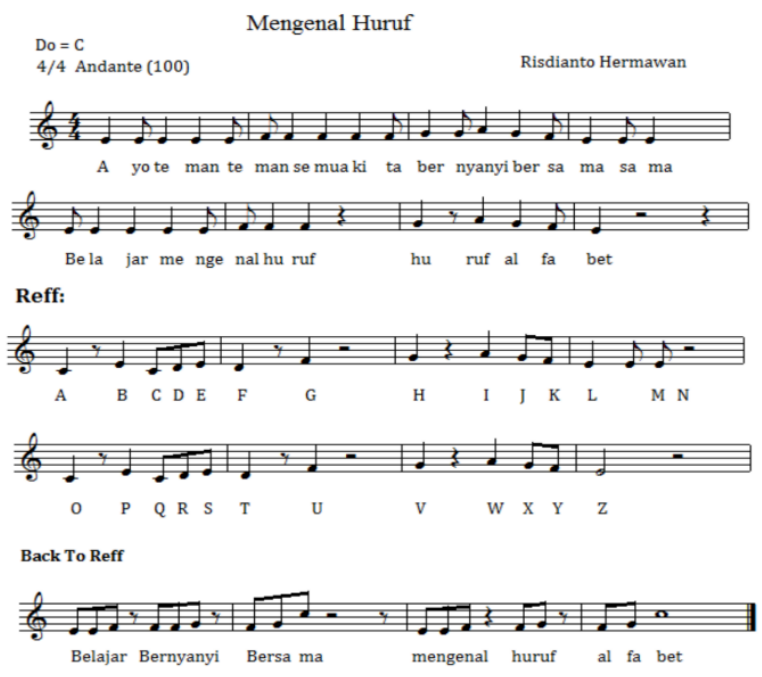

Validation Results of Experts or Music Experts on Prototype Music-Based Learning Models to Introduce Letters and Numbers in Early Childhood

After making the prototype of the music-based learning model is complete, then a validation test is carried out on music experts or experts, namely one of the music teachers at MAN 1 Banyumas and the Al-Azkia Play Group teacher.

The product validation test for the development of a music-based learning model to introduce letters and numbers in early childhood was carried out by Destya Melinda Cindy Armi, S.Pd. He is a music teacher at MAN 1 Banyumas who graduated from UNNES Music Arts who is also a music and choir coach in Banyumas Regency.

Songs that are created according to early childhood songs, Music experts give a score of 5 which indicates that the song is suitable for early childhood. Then in the aspect of musical rhythm, the expert gives a score of 2, this shows that the music rhythm is not suitable in early childhood, in the aspect of suitability of tone selection, the expert gives a score of 4 which means that the tone selection is correct. In the aspect of choosing the tempo, the expert gives a score of 4 which also means that the tempo selection is right according to early childhood development. The suitability of the notation on the bar, the expert gave a score of 2 which means the notation is still not quite right.

From the above assessment, music experts provide suggestions in the form of (1) notes must be in accordance with the rhythm, (2) scores should be made from beginning to end with repetition, and (3) writing musical notes should be accompanied by numerical notation to make it easier for readers.

\section{CONCLUSION}

Music as a learning model in early childhood education to introduce letters and numbers should be used because the music-based learning model will make the learning atmosphere fun. Music-based learning models also tend to make it easier for students to recognize letters and numbers as a basis for reading and counting.

\section{REFERENCES}

Acredolo, Linda, dan Susan Goodwyn. (2010). My Baby Genius 65 Permainan dan Aktivitas yang Melatih Kecerdasan Otak Bayi Anda. Jakarta: PT Bhuana Ilmu Populer. 
Aulia. (2016). Revolusi Pembuat Anak

Candu Membaca. Jakarta:

Flashbook.

Fadlillah, Muhammad. (2016). Desain

Pembelajaran PAUD Tinjauan

Teoretik dan Praktik. Yogyakarta:

Ar-Ruzz Media.

Helmiati. (2012). Model Pembelajaran. Yogyakarta: Aswaja Pressindo.

Majid, Abdul. (2014). Pembelajaran Tematik Terpadu. Bandung: PT Remaja Rosdakarya.

Riyanto, Theo. (2012). Pendidikan Pada Usia Dini. Jakarta: Grasindo.

Sugiyono. (2014). Metode Penelitian Kuantitatif, Kualitatif, dan $R \& D$. Bandung: Alfabeta.

Susanto, Ahmad. (2011). Perkembangan Anak Usia Dini: Pengantar dalam Berbagai Aspeknya. Jakarta: Prenada Media Group.

Thobroni, Muhammad. (2016). Belajar dan Pembelajaran. Yogyakarta: Ar-Ruzz Media. 